ИНФОРМАЦИОННОЕ ПРОСТРАНСТВО. МЕДИАСРЕДА INFORMATION SPACE. MEDIA ENVIRONMENT

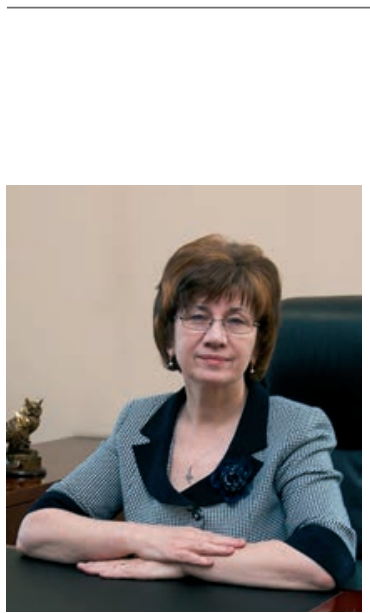

Удк 811.161.1'272:39

DOI 10.17150/2308-6203.2017.6(4).541-554

\begin{abstract}
Музычук Татьяна Леонидовна
Доктор филологических наук, проректор по научной работе
\end{abstract}

Байкальский государственный университет, 664003, Российская Федерация, г. Иркутск, ул. Ленина, 11, e-mail: muzychuk@rambler.ru

Tatiana L. Muzychuk

DSc. in Philology, Vice-Rector for Research

Baikal State University, 11 Lenin St., 664003, Irkutsk,

Russian Federation, e-mail: muzychuk@rambler.ru

\title{
«СПАСИБО, ЧТО ЖИВОЙ : ЭТНОКУЛЬТУРНЫЙ ПОТЕНЦИАЛ РУССКОЙ ЯЗЫКОВОЙ ЛИЧНОСТИ КАК ФАКТОР НАЦИОНАЛЬНОЙ БЕЗОПАСНОСТИ
}

Аннотация. Проблемы изучения этнокультурного потенциала русской языковой личности как основы сохранения национальной самобытности и как фактора национальной безопасности мало изучены и чрезвычайно актуальны. Стремительные изменения социокультурной ситуации, процессы глобализации и поликультурализма привели к серьезным изменениям в обществе. Актуальными стали проблемы консолидации общества, преодоления этнонациональной напряженности и социальных конфликтов, равноправия национальных культур и различных вероисповеданий.

Поиск и сохранение смысловых и языковых характерологических доминант русского языкового этнотипа позволяет противостоять вызовам, рискам и угрозам современности. Национальная культура, являясь ментальной основой коммуникативного поведения, под воздействием иных этнокультурных схем языкового функционирования может меняться, изменяя при этом специфичное для каждой нации коммуникативное поведение языковой личности, что влечет за собой потерю национальной самобытности и национального самосознания.

Системное исследование заявленной проблемы предполагает использование различных подходов к изучению и практическому освоению этнокультурного наследия личности. Согласно первому подходу, изучение сущностных характеристик речевого употребления языкового материала должно сопрягаться со способами его коммуникативной организации в русле этнокультурных параметров. В рамках второго подхода специфика взаимодействия ключевых национальных концептов и языковых структур изучается в аспекте их воздействия на национально-культурную парадигму мышления. В фрункциональной структуре языка бытует компонента, отвечающая за этнокультурный фрормат высказывания и коммуникативное поведение этнотипа. Этнокультурная компонента подвержена изменению, искажению и исчезновению. Для восстановления 
национально-культурных координат требуется, в первую очередь, восстановление коллективной духовно-исторической и культурной памяти общества, позволяющей уверенно ориентироваться в вопросах добра и зла, а значит не допустить потери национальной идентичности, национальной самобытности и искажения самосознания русского народа.

Ключевые слова. Этнокультурный потенциал, русская языковая личность, национальная безопасность, самобытность, поликультурализм, этнонациональная напряженность, равноправие национальных культур, этнотип, коммуникативное поведение, культурная память общества.

Информация о статье. Дата поступления 30 августа 2017 г.; дата принятия к печати 09 октября 2017 г.; дата онлайн-размещения 30 октября 2017 г.

\title{
"THANK YOU FOR BEING ALIVE»: ETHNOCULTURAL POTENTIAL OF THE RUSSIAN LINGUSTIC PERSONA AS A FACTOR OF NATIONAL SECURITY
}

\begin{abstract}
The issues of studying the ethnocultural potential of the Russian linguistic persona as the basis for keeping the national identity and a factor of national security are understudied and are of the immediate interest. Rapid changes of the sociocultural situation, the processes of globalization and polyculturism have resulted in serious changes in society. The problems of society consolidation, overcoming ethnonational tensions and social conflicts, equality of national cultures and different confessions have become urgent.

Search and preservation of semantic and linguistic keynotes of the Russian language ethnotype enables us to confront challenges, risks and threats of the modern age. Being the mental basis for communication behavior, a national culture can change under the influence of other ethnocultural patterns of the language functioning, thus changing the specific for a particular nation communication behavior of the linguistic persona, which results in losing national identity and national consciousness.

Systemic research into the issue stated implies using different approaches to studying and adopting ethnocultural heritage of the linguistic persona. In accordance with the first approach, studying the essential characteristics of language usage should be correlated to how communication is organized in lines with ethnocultural parameters. In the framework of the second approach, the specific character of the interaction of the key national concepts and language structures is studied from the point of view of their impact on the national-cultural thinking paradigm. The functional structure of the language possesses a component responsible for ethnocultural format of utterances and communication behavior of the ethnotype. The echnocultural component is prone to change, distortion and disappearance. To restore national and cultural characteristics it is required to, first of all, restore the spiritual, historic and cultural memory of the society, allowing it to tell good from evil at all times, and therefore, not allowing it to lose the national identity and distort the Russian people's consciousness.
\end{abstract}

Keywords. Ethnocultural potential, Russian linguistic persona, national security, national identity, polyculturism, ethnonational tensions, equality of national cultures, ethnotype, communication behavior, cultural memory of the society.

Article info. Received August 30, 2017; accepted October 09, 2017; available online October 30, 2017. 
Призадуматься и присмотреться, поразмыслить, покуда живой.

Булат Окуджава

\section{Введение}

В 1942 г. по фронтам Великой Отечественной войны, по городам и весям многонациональной, многомиллионной и многострадальной страны как заклинание и как молитва прозвучали слова Анны Ахматовой: «Мы знаем, что ныне лежит на весах...». Удивительно точно поэтесса обозначила национальную идею огромной страны - объединиться для защиты великого русского слова, русского языка, русской речи, дающей осознание, что мы единый народ, многоязыкий, но единый, и страна у нас одна. Спасти русское слово от плена - значит спасти народ, нацию и государство:

\section{Свободным и чистым тебя} пронесем,

И внукам дадим, и от плена

Навеки.

спасем

Объединились, победили и спасли. Но не навеки, как оказалось. До сих пор продолжаем спасать от плена русское слово и общую историю: и в маленькой непризнанной республике Приднестровье, и на полуострове Крым, и в Донбассе, и в бывших республиках Советского Союза, и, к великой скорби, в России, у себя на родине.

Русский мир, вот уже 26 лет переживающий трагедию распада единого государства, за существование и возрождение которого совершались боевые и гражданские подвиги миллионами людей разных национальностей и вероисповеданий, только сейчас начинает приходить к пониманию, что укрепление русского языка, сохранение русской культуры и духовности является гарантией как личной безопасности, так и национальной безопасности многоконфессиональной страны, «способствует защите геополитических интересов России и повышению ее международного авторитета». Вопрос охраны и защиты русского национального языка как основы сохранения безопасности поликультурного русского государства сегодня стоит особенно остро и требует незамедлительного решения. Еще великий А. С. Пушкин завещал русскому языку двуединую миссию миссию единения и миссию сбережения иных языков и культур. Понимая, что сила и величие народов, населяющих «шестую часть земли с названьем кратким "Русь"», в сбережении русского языка, духовном носителе самостоятельности нации, «власть предержащие» многих государств на протяжении нескольких столетий не оставляют надежды «ассимилировать» язык русского государства, а точнее, «уничтожить».

Как этнологический термин «ассимиляция» ${ }^{1}$ обозначает этническую, частичную или полную утрату культуры в пользу другой. Перевод с латинского - «подражание, уподобление, сходство» - в период цивилизационных конфрликтов нового времени звучит как предупреждение и воспринимается как обозначение этапов постепенного подавления

${ }^{1}$ Ассимиляция (от лат. assimilatio - подражание, уподобление, сходство) этническая, частичная или полная утрата культуры в пользу другой, обычно доминирующей культуры, включая и смену этнической идентичности (Словарь этнологических терминов, 2012). URL : https://slovar.cc/etnograf/ etno-term.html. 
самосознания одной цивилизации другой. Цель - отсечение народа от глубокого понимания общности в рамках своей цивилизации как фундаментальной опоры сохранения и развития уникальных традиционных ценностей, общей истории, культуры, вероисповедования и языка. Сначала - подражаем, потом уподобляемся, наконец - становимся частью чужой цивилизации, теряя свою уникальность, свое лицо (сходство).

Не менее красноречив и медицинский термин, определяющий «ассимиляцию» ${ }^{2}$ как «процесс усвоения организмом веществ, поступающих в него из окружающей среды, в результате которого эти вещества становятся составной частью биологических структур». Ключевое словосочетание - «составной частью».

Руслан Александрович Лынёв (1939-2012), советский и российский журналист и литератор, в статье «Еще раз о “трудных вопросах" истории польско-российских отношений» приводит слова Юзефа Пилсудского ${ }^{3}$, сказанные им накануне Первой Мировой войны Богуславу Медзиньскому ${ }^{4}$. Будущий

${ }^{2}$ Ассимиляция (лат. assimilatio уподобление, усвоение; син. анаболизм) - процесс усвоения организмом веществ, поступающих в него из окружающей среды, в результате которого эти вещества становятся составной частью биологических структур или откладываются в организме в виде запасов (Малая медицинская энциклопедия. М., 1991-1996).

${ }^{3}$ Пилсудский Юзеф (1867-1935), лидер небольшой Польской социалистической партии и руководитель стрелкового клуба в Галиции, признанного террористическим движением, польский государственный деятель, маршал Польши (1920 г.).

${ }^{4}$ Богуслав Медзиньский - руководитель Польской военной организации в австрийской оккупационной зоне. маршал Польши страстно мечтал «взять» Москву и написать на стене Кремля: «Говорить по-русски запрещено». Однако «взять» не удалось ни полякам, ни французам, ни немцам...

В русском языке есть выражение «взять языка», пришедшее из древнеславянской речи практически в неизмененном виде и изначально звучащее как «захватить языка». Выражение «захватить языка» начинает встречаться в письменных источниках в начале шестого столетия нашего времени в рассказах Прокопия Кесарийского ${ }^{5}$, в трактатах императора Маврикия ${ }^{6}$, в военных переводах Катакалона Кекавмена ${ }^{7}$ и неизменно обозначает пленение противника и получение информации определенного рода. В современных условиях ведения информационно-психологических войн

5 Прокопий Кесарийский (между 490 и 507 - после 565 г.) - до крещения Неаний

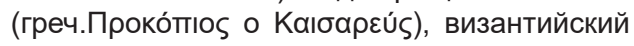
писатель; секретарь полководца Велизария; христианский святой, почитаемый в лике великомучеников.Его произведения отличает литературное мастерство, историческая достоверность. Самое крупное по объему произведение Прокопия Кесарийского «История войн» в восьми книгах. Выражение «захватить языка» встречается в рассказе об осаде города Ауксимо (Озимо) в Италии в 539 г.

6 Флавий Маврикий Тиберий Август (539 г. - 27 ноября 602 г. (греч. ФАа́ßıо

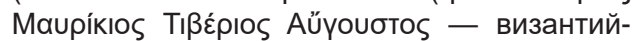
ский император. Выражение «захватить языка» встречается в трактате о военном искусстве «Стратегикон» (595-602 гг.), в котором содержатся, в частности, ценные сведения о славянах (595-602 гг.).

${ }^{7}$ Катакалон Кекавмен (1015 или 1020 гг. - после 1078 г.) - итальянский полководец, предположительно автор «Советов и рассказов», источника по истории XI в. 
выражение «взять языка», «захват языка» приобретает особый смысл. Главным врагом нарекается язык непокоренного народа как система понятий и основа его общественного сознания. Через язык, как средство накопления исторической памяти народа, идет передача социального, культурного опыта, норм и традиций, осуществляется преемственность поколений, воплощенных в идентичности языковой личности. Поэтапный инокультурный захват языка ведет вначале к постепенному, а затем стремительному изменению образа мыслей, модификации общественного сознания и трансформации культурного кода. Экспорт иного языка в русскую письменную и устную речь (разговорную речь, официально-деловую речь, научную речь, языковое топонимическое пространство русских городов и другое) открывает дверь в мир управления нашим сознанием извне, в мир манкуртов. И возврата из этого мира нет. В нем не существует ни родины, ни памяти, ни души, ни кровных связей, ни зова предков. Ни прошлого, ни будущего. Как ни пыталась Айман-Ана, героиня романа Чингиза Айтманова «И дольше века длится день», со всей страстью материнского чувства вернуть хотя бы на миг память сыну-манкурту, но не узнал он матери, не тронули его страдания и слезы женщины и слова, исполненные боли и муки: «Вспомни, чей ты? Чей ты? Как твое имя? Имя? Твое имя Жоламан. Ты слышишь? Ты Жоламан. А отца твоего звали Доненбай. Разве ты не помнишь отца? Ведь он тебя с детства учил стрелять из лука. Твой отец Доненбай! Доненбай, Доненбай. А я твоя мать. А ты мой сын. Ты из племени найма- нов, понял? Ты найман...». И управляемый словом хозяина, он натянул тетиву на стреле...

\section{Гипотеза}

В функциональной структуре языка бытует компонента, отвечающая за этнокультурный формат высказывания и коммуникативное поведение этнотипа. Этнокультурная компонента подвержена изменению, искажению и исчезновению. Для восстановления национально-культурных координат требуется, в первую очередь, восстановление коллективной духовно-исторической и культурной памяти общества, позволяющей уверенно ориентироваться в вопроcax добра и зла, а значит не допустить потери национальной идентичности, национальной самобытности и искажения самосознания русского народа.

\section{Из истории вопроса}

Рассуждая об оторванности человека от своих корней, русский православный философ Иван Александрович Ильин в «Книге раздумий» (1938-1939) пишет, что это есть большая опасность, «большая беда» в современном мире: «потерявшая корни жизнь становится противоестественной; лишенная корней душа - безбожной. Затем наступает развязка: человечество разрушается» [1, С. 115].

Вероятно, это мысль была положена в основу доктрины Аллена Даллеса, американского дипломата и руководителя резидентуры Управления стратегических служб в Берне (Швейцария): «человеческий мозг, сознание людей способны к изменению». Сразу после окончания Отечественной войны, в период «хо- 
лодной войны», он писал, что «для развала СССР не надо атомной бомбы, нужно только внушить его народам, что они смогут обойтись без знания русского языка, нарушатся экономические, культурные и другие связи, и государство перестанет существовать. Посеяв в сознании людей хаос, мы неизменно подменим их ценности на фальшивые и заставим их в эти фральшивые ценности верить. Как? Мы найдем своих единомышленников, своих союзников в самой России. Эпизод за эпизодом будет разыгрываться грандиозная по своему масштабу трагедия гибели самого непокорного народа, окончательного, необратимого угасания его сознания» ${ }^{8}$ [курсив наш - Т. М.]. Последователи А. Даллеса предпринимают сегодня яростное и беспощадное наступление на русский национальный язык и русское православие, прекрасно понимая, что феномен «русского духа» неотделим от русского языка - своеобразного генофонда национальной культуры и консолидирующей силы народа, и православия - основы духовно-нравственного и патриотического воспитания нации.

На рубеже веков многонациональный непокорный русский народ уже пережил не один трагический эпизод, описанный в так называемой программе Даллеса - Бжезинского. Мы познали гласность, жили по талонам, вошли в рыночную экономику, были облагодетельствованы ваучерами. Создали телевидение «трупов и катастроф, и молодеж-

\footnotetext{
${ }^{8}$ Фонд стратегической культуры. URL : http://www.fondsk.ru/pview/2011/08/12/escheo-trudnyh-voprosah-istorii-polsko-rossijskihotnoshenij-4370.html.
}

ного жаргона и морального растления», бросались под танки у Белого дома, были свидетелями и участниками трагедии русского и чеченского народов, разрешили ненормативную лексику на ТВ, в театре и кино, читали книги, в которых преступники, наркоманы, маньяки, люди «не в себе» и бездельники были главными персонажами. Еще мы беззастенчиво знакомились с килограммами порнографической продукции... Публично осмеивали семейные, личные, православные и государственные ценности. И позволили захват родного языка и родной речи иной культурой.

Мы забыли, что слово «язык» в Древней Руси имело и второе значение - «народ», а значит агрессия, направленная сегодня против русского языка, направлена, в первую очередь, против русского народа и государственности. Русский язык, фрактор консолидации народов России и русскоговорящих за рубежом, стремительно теряет позиции: «за последние 20 лет количество говорящих в мире на русском языке снизилось примерно на 120 млн человек» ${ }^{9}$. Продолжает падать и речевая культура носителей русского языка: «около 40 тысяч слов из словаря В. И. Даля можно считать полностью вышедшими из употребления, в течение года люди ничего не искали с помощью этих слов и даже не спрашивали про их значение» ${ }^{10}$.

${ }^{9}$ Еремина В. Число русскоговорящих в мире за последние 20 лет снизилось более чем на 100 млн человек // ИТАР-ТАСС. М., 2013. URL : http://tass.ru/obschestvo/831953

10 Почти 20\% слов из словаря Даля полностью вышли из употребления // ТАСС. М., 2016. URL : http://tass.ru/obschestvo/3821416. 


\section{Заимствование как чужие цен- ностные ориентиры}

Пока лингвисты, историки и рядовые граждане на страницах научных журналов, периодической печати, в пространстве Интернета, на конференциях и симпозиумах ведут жаркие споры о засилье иноязычной лексики и неправомерных сокращениях названий исторических событий, святых мест, памятных дат (ветераны ВОВ, РПЦ сегодня, территория XXC, гражданинРФ, подарки на НГ и др.), - журналисты, газетчики, люди, делающие бизнес, вбрасывают массовому потребителю очередную порцию англицизмов: рисайлинг (утилизация), печворк (лоскутное шитьё или изделие из разноцветных лоскутов), мувимейкер (кинорежиссер), нетворкинг (социальная и профессиональная деятельность или установление деловых контактов), прокрастинатор (человек, отлынивающий от обязательств, стремящийся отложить дела или неприятные мысли на потом), при́квел и др.

Например: Первые шаги по использованию роторных дробилок для рисайлинга в Москве следует отнести к 1996 г., когда на территории Очаковского кирпичного завода была смонтирована и запущена в эксплуатацию линия по рисайлингу с роторной дробилкой СМД-86А в качестве первичного дробильного агрегата [2].

См.: Пэчворк можно шить вручную или на машине (Википедия).

См. еще: Наверно, практически каждый бизнесмен и предприниматель знает о том, что нетворкинг (установление деловых контактов) является самым эффрективным и наименее дорогим ин- струментом активизации бизнеса. Тем не менее, немногие занимающиеся бизнесом люди хорошо понимают, как заниматься нетворкингом. В этой области важно уметь выделяться и запоминаться ${ }^{11}$.

Еще примеры: Продам коллекцию подставок (бирдекели) под пивные бокалы разных брендов 51 штука!"12 (объявление на сайте).

Авторы некоторых текстовых фрагментов поясняют значение новомодных слов. Однако в большинстве случаев этого не происходит и значение иностранного слова в русском тексте остается для большей части читателей не ясно, многозначный «инородец» как-то плохо вживается в контекст русского предложения, отсекая русского человека от родного языка и настойчиво отсылая его к другой ментальности, чужому опыту, чужой культуре.

Так, пэчворк - это лоскутная техника, вид рукоделия, при котором по принципу «мозаики» сшивается цельное изделие из кусочков ткани (лоскутков). Выражение «шить вручную или на машинке вид рукоделия, лоскутную технику» звучит как-то не по-русски. Если пэчворк употреблено во втором значении как «одеяло, покрывало, изделие из разноцветных лоскутов», то почему не назвать вещь русским словом - лоскутное одеяло.

То же самое можно сказать и об употреблении слова «бирдекель». Бирдекель (немец.) - это крышка, предназначенная для предотвращения попадания в пивную кружку листьев, насекомых и других по-

${ }^{11}$ URL : http://business.damotvet.ru/ marketing/22190.htm.

12 URL https://ok.ru/group/ $45011161382996 /$ topic/66925100163156. 
сторонних предметов, подается с пивной кружкой на открытом воздухе (например, в летних кафе). Употребление слова бирдекель в значении подставки под кружку, предназначенной для защиты стола от царапин и капель пивной пены, ошибочно. Употребление - ошибочно, а использование крышки как подставки, конечно, возможно. Бирдекель... Печворк...звучит значительно, поевропейски. Совсем как «Фемистоклюс!» из уст героя известного произведения. Произнесли, употребили и словно прикоснулись к недосягаемым западным ценностям, словно отряхнули с себя «русское патриархальное», стали на шаг ближе к цивилизованному европейскому миру. А лоскутное одеяло, с любовью шитое нашими бабушками, необыкновенно красивое, излучающее душевное тепло и уют, в мыслях уводящее нас в сказку, в ромашковый луг, в детство, так некстати напоминает европеизированной части населения о российской глубинке и русской печи.

Еще пример: У резни в Сургуте появился приквел ${ }^{13}$. 19 августа 2017 г. в центре Сургута произошла трагедия, унесшая жизни людей. Слово «приквел», введенное в контекст заголовочной части статьи, безответственно и бессовестно смещает смысловые акценты, погружая событие в контекст компьютерных игр и киноиндустрии.

При́квел (англ. prequel, контаминация приставки pre- (до) и sequelпродолжение) - книга, кинофильм или компьютерная игра, время действия которых происходит до

${ }^{13}$ URL : https://www.gazeta.ru/army/2017/ 08/22/10845986.shtml. событий ранее созданного произведения и предшествующие им по внутренней хронологии.

Вольное обращение с лексикой родного языка приводит к тому, что для нового поколения русский язык перестает быть носителем культурных и духовных традиций, голосом совести, а значит, искажается языковая картина мира русского человека, а его новая словесная модель снимает все моральные запреты и проблемы. Во взаимодействии языков обязательно должна быть творческая мера, которая, по абсолютному убеждению И. А. Ильина, «в духовном общении и взаимодействии народов лучше всего обретается живым, расцветающим творчеством самого народа».

Однако творческая энергия народа расцветает не тем цветом и все норовит что-нибудь эдакое выдать, выдумать, как говаривал Манилов из «Мертвых душ» Н. В. Гоголя, «...какую-нибудь этакую науку, чтобы этак расшевелило душу, дало бы, так сказать, паренье этакое...». Но если гоголевский герой все-таки понимает, «что несколько зарапортовался», то мы не замечаем опасности в бездумном служении знаку: НГ (Новый год), ПВЛ («Повесть временных лет»).

Например: Детям из малоимущих семей в Иркутской области подарили на нГ конфеты с червями. (10.01.2017, источник: FlashSiberia $)^{14}$.

Еще: НГ в Берлине на аллее (информация на YouTube).

Коллеги! Друзья! НГ наступил как всегда (из поздравления). Важность и истерия, связанная в

${ }^{14}$ FlashSiberia : информ. агентство. URL : http://flashsiberia.com/. 
НГ, сойдет на нет, и останется просто праздник НГ, который не обязательно обожествлять ${ }^{15}$.

ПВЛ - памятник, пронизанный идеями глубокого общерусского патриотизма. ПвЛ отвечает на поставленный в ее заголовке вопрос «откуда пошла Русская земля» [3, C. 581].

Исчезает слово, а с ним глубинный смысл, образ, чувство, душа, коллективная память, жизнь и совесть слова. С. Н. Булгаков, русский фрилософ, богослов, в сочинении «Философия имени», опубликованном в 1920 году, об «искусственно созданных путем алгебраического сложения "словах-манекенах"» писал, что такие слова «становятся вампирами, получают свою жизнь, свое бытие, силу. Образуют целое облако таких мертвых слов-ларв, вампиров, которые сосут кровь языка...» [4, С. 34].

Создавая и меняя языковую среду своего бытия, мы не задумываемся над возможными последствиями своих действий, «невинного» словотворчества и безграничной распахнутости для всего иностранного.

А создаваемая нами среда на пике своей сформированности, полностью выместив прежнюю среду, станет явно зримой и агрессивно активной. И только в этот момент придет осознание утраты культурной идентичности, мы будем пытаться вернуть утраченное в условиях критического уровня социального напряжение в обществе. А вместе с тем, мы сами наполняем свой язык, свою культуру и историю, по меткому

${ }^{15} \mathrm{URL}$ : http://pushba.livejournal.com/ 1505123.html. выражению И. Ильина, «полою водою иноземщины».

Людмила Алексеевна Вербицкая, фрилолог-русист, Президент Международной ассоциации преподавателей русского языка и литературы (МАПРЯЛ), Председатель Попечительского совета Фонда «Русский мир», в статье «Язык и общество. Роль языка в жизни общества» приводит неутешительную статистику: «...если в период с 1960 по 1985 гг. заимствованных слов насчитывалось всего 9 тыс., то с 1986 г. (перестройка в России) ежегодно добавлялось по 2 тыс., т.е. за последние 20 лет - более 40 тыс. Это действительно огромное количество, значительно превосходящее активный словарный запас даже высокообразованного человека» [5, С. 12].

Безусловно, в лексическую базу русского языка в разное время вливается определенное количество заимствованных слов, однако в эпоху всеобщей глобализации и информатизации этот процесс «вливания» стал угрожающим.

Глобализация и информатизация ведет, а точнее, гонит народы к языковой унификации, объективно подготавливая переход к мировому моноязыку, а именно английскому языку. И хотя почти все страны в мире являются многоязычными (исключением является Исландия), однако только отдельные страны и этносы пытаются противостоять этому. Согласно данным известного справочника по языкам мира Ethnologue («Этнолог: Языки мира»), сегодня известно 7106 отдельных живых языков, на которых говорят по всему миру, в то время как стран (включая так называемые зависимые территории и территории с неопределен- 
ным статусом) насчитывается 270. Представленные данные наглядно показывают, что проблема языковой неоднородности присутствует практически повсеместно, однако в ситуации нарастающей глобализации отдельные государства окончательно теряют монополию на управление своим собственным языком. И Россия не исключение. С. Хантингтон, американский социолог и политолог, автор концепции этнокультурного разделения цивилизаций, рассматривая проблему связи языка и культуры, отмечает, что происходит распространение и интернационализация культурных ценностей и идеологии западной интеллигенции. Посредниками в этом процессе выступают различные фонды, научные сообщества, неправительственные организации и межнациональные учреждения, выполняющие социальную или культурную миссию [6, 115-119].

Английский язык выдвинулся на первый план и в научно-технической среде, поскольку ни одно научное открытие, изобретение или серьезная идея не могут получить широкого международного признания, не будучи изложенными на английском языке. Публикации в базах данных Scopus $и$ Web of Science являются сегодня главными показателями результативности научной деятельности отечественных ученых, без определенного количества таких публикаций практически невозможно подать заявку на грантовые проекты. Научное сообщество все чаще и чаще задается вопросом: почему российский ученый-исследователь должен писать по стандарту, принятому на Западе, почему он обязан для них переводить свои статьи на английский, «продвигать» или «предлагать» себя потенциальному иностранному читателю, расти до каких-то труднообъяснимых и труднодостижимых высот англоязычной науки? Нам мягко навязывают условия игры, но жестко контролируют их выполнение.

Вернемся еще раз к высказыванию А. Даллеса, изложенному в «Размышлениях о реализации американской послевоенной доктрины против СССР» (1945г.): «Из литературы и искусства мы, например, постепенно вытравим их социальную сущность, отучим художников, отобьем у них охоту заниматься изображением, исследованием тех процессов, которые происходят в глубинах народных масс. Литература, театры, кино - все будут изображать и прославлять самые низменные человеческие чувства. Мы будем поддерживать и поднимать так называемых художников, которые станут насаждать и вдалбливать в человеческое сознание культ секса, насилия, садизма, предательства - словом, всякой безнравственности... Честность и порядочность будут осмеиваться и никому не станут нужны... Хамство и наглость, ложь и обман, пьянство и наркомания, национализм и ненависть к русскому народу - все это мы будем ловко и незаметно культивировать... и лишь немногие, очень немногие будут догадываться или понимать, что происходит... Но таких людей мы поставим в беспомощное положение, превратим в посмешище, найдем способы оболгать и объявить отбросами общества. Будем... опошлять и уничтожать основы народной нравственности» [7, C. 186]. 
Надо признать, что многое из этих программных пунктов выполнено. А чтобы тех, кто сейчас догадывается, что происходит, ловко и незаметно не ввели в глубокое и агрессивное заблуждение, а тех, кто уже понимает, что происходит, не объявили отбросами общества, нужно хранить и охранять чистоту русской речи как важнейшую силу, объединяющую наш народ, наши культурные и духовные ценности.

\section{Роль русского языка в сохра-} нении и поддержании единства современного российского социума

За национальные ценности как платформу, на которой стоит российская государственность, в настоящее время уже необходимо активно бороться и понимать, что «выбьют» эту платформу у многонационального народа - повиснет он на экономической удавке быстро развивающихся соседей и толерантных партнеров. Поэтому и «демонтируется» русский язык, крушатся исторические памятники русского народа, горят фонды древнерусской литературы, не возвращаются музейные экспонаты на историческую родину. В клочья рвут, прежде всего, не экономику, а связующую нить времен и поколений - язык, названный советским лингвистом Владиславом Иллич-Свитычем «бродом через реку времени, он ведет нас к жилищу ушедших; но туда не сможет прийти тот, кто боится глубокой воды».

На фроне усиления этнонациональной напряженности и социальных конфликтов в обществе Правительство принимает ряд срочных и действенных мер. Создаются фонды, разрабатываются программы и проекты для защиты и поддержки русского языка на краткосрочные и дальнесрочные перспективы. Проблемы языка решаются на самом высоком уровне и с привлечением фринансовых ресурсов. Так, Государственная Дума еще в 2005 г. принимает закон «О государственном языке Российской Федерации», претерпевший две редакции, в 2013 и 2014 гг.

$$
\text { В } 2007 \text { г. создается фронд }
$$
«Русский мир» согласно Указу Президента Российской Федерации В. В. Путина. Основная цель Фонда - «популяризация русского языка, являющегося национальным достоянием России и важным элементом российской и мировой культуры, и поддержка программ изучения русского языка в Российской Федерации и за рубежом». Проект «Русский мир» предоставляет России новые возможности сотрудничества с остальным миром, открывает собственные пути развития, объединяя всех, кто осознает свою причастность к России. Это русские, россияне, наши соотечественники, живущие в бывших республиках Советского Союза, это иностранные граждане, изучающие русский язык и интересующиеся русской культурой.

В феврале 2010 года ООН учредила День русского языка, который россияне ежегодно отмечают 6 июня - в день рождения поэта А. С. Пушкина. Был возрожден День славянской письменности и культуры, который празднуется 24 мая в день памяти святых равноапостольных братьев Мефодия и Кирилла, основоположников славянской письменности. В 1991 году Постановлением Президиума Верховного 
Совета РФ праздник получил статус государственного, а с 2010 г. было решено, что столицей Дней славянской письменности и культуры станет Москва. Митрополит Воронежский и Борисоглебский Сергий назвал этот день «праздником начала государственности цивилизованной России, праздником нашей благодарной памяти, напоминающим нам о назначении жизни человека» ${ }^{16}$.

В 2015 г. Правительством РФ утверждается Федеральная целевая программа «Русский язык», предусматривающая развитие, распространение и продвижение русского языка в 2016-2020 годах с объемом финансирования 7,6 млрд рублей. Одна из главных ее целей — продвижение русского языка в других странах.

Можно назвать еще ряд проектов, призванных оказывать «содействие распространению объективной информации о современной России, российских соотечественниках и формированию на этой основе благоприятного по отношению к России общественного мнения»; поддерживать «деятельность российских диаспор за рубежом по сохранению их культурной идентичности и русского языка», а также деятельность «национальных и международных организаций и объединений преподавателей русского языка и литературы», «общественных и некоммерческих организаций, профессиональных объединений, научных и образовательных учреждений, предметом деятельности которых являются исследования и разработки методик преподавания и 0/433/1/ программ изучения русского языка и литературы, исследование истории и современной России».

Ожидается увеличение к концу 2020 года в 1,5 раза доли русских школ (классов) за рубежом, получивших адресную поддержку, включая поставку учебно-методических материалов, в 10 раз количества качественных Интернет-ресурсов, позволяющих изучать русский язык, получать информацию о русском языке, российском образовании, культуре России, и в 2,2 раза количества учебников, учебных пособий, научно-популярных книг и журналов по русскому языку, литературе и культуре России, поставленных в российские центры русского языка в государствах СНГ.

Культуру и русский язык как основную ее часть сегодня возвели в ранг национальных приоритетов и признали ее важнейшим фактором гармонизации общественных отношений, залогом динамичного социально-экономического развития, гарантом сохранения единого культурного пространства и территориальной целостности России

Однако, несмотря на то, что государственная политика сегодня направлена на поддержку культуры, государственного языка, ни в одном документе нет обеспокоенности состоянием современной языковой среды жителей городов и поселков России. Пока мы укрепляем русский мир за рубежом, русский мир внутри страны ослабевает, разъединяется и распадается. Можно говорить о величии русского слова в школе, находить явные и скрытые смыслы в произведениях великих русских писателей, однако школьники и студенты, покинув учебные классы 
и аудитории, в которых несколько минут назад говорили о культуре русской речи и вкладе русской культуры в мировую цивилизацию, попадают в мир, где отсутствует по определению русское слово и русский дух.

\section{Заключение}

Англоязычная лексика захватила почти все языковое городское пространство Сибири и Дальнего Востока. Мы неоднократно писали, что на центральных улицах исторического центра сибирского города до 60-90 \% англоязычной лексики. Настораживает, что за последний год наименования городских учреждений, перечень предоставляемых ими услуг, рекламные баннеры активно переводятся на китайский язык, даже распахнутые двери православных храмов встречают нас плакатами, испещренными китайскими иероглифами и невольно нарушающими тонкое душевное состояние, с которым входишь в храм. Народная мудрость гласит: «Не вспоя, не вскормя, ворога не наживешь (не увидишь)». «Выцеловал ястреб курочку до последнего перышка».

Современный процесс заимствования, «игромании» и заигрывания с лексикой родного и чужих языков давно вышел за рамки заполнения понятийных лакун, языковая како- фония, захватившая среду обитания русского человека, имеет психоэмоциональные предпосылки и вызывает устойчивые ассоциации с иной культурой (отличной от российской). Создаются тексты, которые не принадлежат ни иностранной, ни русской культуре, создается новая языковая среда на территории российского государства. «Инородцы» и так называемый «Новояз» уже стали неотъемлемой частью повседневного языкового опыта русскоговорящих и вполне «могут выступать моделями для дальнейшего языкового поведения, не характерного для русской культурно-языковой традиции» [8, С. 5].

В настоящее время в России успешно реализуется федеральный проект «Комфортная городская среда», направленный на поэтапное благоустройство дворовых территорий, приведение в порядок парков и скверов, организацию освещения, ремонта тротуаров, озеленение, установку детских площадок. Важным достижением нового национального проекта, бесспорно, является модернизация коммунальной инфраструктуры, которая синхронизируется с благоустройством. К сожалению, в содержание нацпроекта «Комфортная городская среда» не включено понятие «комфортная языковая среда» как духовная территория россиян...

\section{СПИСОК ИСПОЛЬЗОВАННОЙ ЛИТЕРАТУРЫ}

1. Ильин И. А. Книга раздумий и тихих созерцаний / И. А. Ильин. - М. : Альта-Принт, 2008. - 527 c.

2. Балагула В. Я. Опыт сноса домов с последующей переработкой строительных отходов [Электронный ресурс] / В. Я. Балагула, О. Л. Санько // Laboratory.Ru - Режим доступа: http://masters.donntu.org/2007/feht/stepanovm/library/lib4.htm.

3. Творогов О. В. Лексический состав «Повести временных лет»: словоуказатели и частотный словник / О. В. Творогов // Полное собрание русских летописей. - М., 2001. - T. 1. - C. 581-601. 

$334 \mathrm{c}$.

4. Булгаков С. Н. Философия имени / С. Н. Булгаков. - М. : Директ-Медиа, 2014. -

5. Вербицкая Л. А. Язык и общество. Роль языка в жизни общества / Л. А. Вербицкая // Педагогика. - 2015. - № 2. - С. 3-18. $603 \mathrm{c}$.

6. Хантингтон С. Столкновение цивилизаций / С. Хантингтон. - М. : АСТ, 2003. -

7. Анцупов А. Я. Конфрликтология в схемах и комментариях / А. Я. Анцупов, С. В. Баклановский. - СПб. : Питер, 2013. - 306 с.

8. Бойко С. А. Когнитивный анализ англицизмов с точки зрения ориентирующей функции языка (на материале текстов современной российской рекламы) : автореф. дис. ...канд. фрилол. наук: 10.02. 19 / С. А. Бойко. — Улан-Удэ, 2016. — 21 с.

\section{REFERENCES}

1. Il'in I. A. Kniga razdumii i tikhikh sozertsanii [Book of Thoughts and Quiet Contemplation]. Moscow, Al'ta-Print Publ., 2008. 527 p.

2. Balagula V. Ya., San'ko O. L. A Practice of House Demolitions and Further Recycling Construction Waste. Laboratory.Ru. Aviable at: http://masters.donntu.org/2007/feht/ stepanovm/library/lib4.htm.

3. Tvorogov O. V. The Primary Chronicle's (the Tale of Bygone Years') Glossary: Concordance and Frequency Lists. Polnoe sobranie russkikh letopisei [Complete Collection of Russian Chronicles]. Moscow, 2001, vol. 1, pp. 581-601.

4. Bulgakov S. N. Filosofiya imeni [Proper Name Philosophy]. Moscow, Direkt-Media Publ., 2014. 334 p.

5. Verbitskaya L. A. Language and Society. A Language Role in Life of Society. Pedagogika = Pedagogy, 2015, no. 2, pp. 3-18. (In Russian).

6. Huntington Samuel P. The Clash of Civilizations and the Remaking of World Order. New York, Simon \& Schuster, 1996, 398 p. (Russian ed.: Khantington S. P. Stolknovenie tsivilizatsii. Moscow, AST Publ., 2003. 603 p.).

7. Antsupov A. Ya., Baklanovskii S. V. Konfliktologiya v skhemakh i kommentariyakh [Conflictology through Schemes and Commentaries]. Saint Petersburg, Piter Publ., 2013. $306 \mathrm{p}$.

8. Boiko S. A. Kognitivnyi analiz anglitsizmov s tochki zreniya orientiruyushchei funktsii yazyka (na materiale tekstov sovremennoi rossiiskoi reklamy). Avtoref. Kand. Diss. [The Cognitive Analysis of Anglicisms from the Viewpoint of the Orientation Language Function (Based on Modern Russian Advertisements) Cand. Diss. Thesis]. Ulan-Ude, 2016. 21 p.

\section{ДЛЯ ЦИТИРОВАНИЯ}

Музычук Т. Л. «Спасибо, что живой»: этнокультурный потенциал русской языковой личности как фрактор национальной безопасности / Т. Л. Музычук // Вопросы теории и практики журналистики. - 2017. - T. 6, № 4. - С. 541-554. DOI: 10.17150/23086203.2017.6(4).541-554.

\section{FOR CITATION}

Muzychuk T. L. «Thank You for Being Alive»: Ethnocultural Potential of the Russian Lingustic Persona as a Factor of National Security. Voprosy teorii $i$ praktiki zhurnalistiki = Theoretical and Practical Issues of Journalism, 2017, vol. 6, no. 4, pp. 541-554. DOI: 10.17150/2308-6203.2017.6(4).541-554. (In Russian). 